\section{可塑性と物理療法一物理的エネルギ 一による運動障害の機能回復一}

日下病院

川村 次郎

大阪府立看護大学総合リハビリテーション学部理 学療法学専攻

林義孝

\section{はじめに}

本稿の目的は，物理的エネルギー（物理療法） による運動障害の機能回復の可能性について検討 することである.

\section{生体組織の可塑性と理学療法}

可塑性または塑性は，力を除いても変形したま ま元の形に戻らない粘土のような性質を意味する 言葉である.リハビリテーション（以下，リハ） 関係者には可塑性という言葉から脳の可塑性を， さらには sproutingによるシナプス結合の可塑性 を思い浮かべる人があるかもしれないが1)，生体 組織は一般的に刺激に反応してその構造, 形状, 機能などをリモデリング (再構築) する可塑性を 有している. 可塑性は成長期に限定されるもので はなく，生涯を通じて見られるものである22.

可塑性の視点からすると, 運動障害の機能回復 に物理的エネルギーを使用するのが理学療法であ り, 理学療法の中で療法士による徒手的運動（他 動運動）または患者自身による運動（自動運動） を使用するのが運動療法（Therapeutic Exercise), 機器を使用して電気, 温熱, 光線, 機械 的などの物理的エネルギーを加えるのが物理療法 (Physical Agents) と考えることができる3).

\section{運動療法と物理療法の役割分担に 合理性はあるか}

わが国で物理療法（いわゆる物療）と呼ばれて いる領域は，英語では Physical Agents として一 まとめにされている治療法とほぼ致する4).
Physical Agents は運動療法の補助としてか, 臨 床症状の軽減のための対症療法として使用され, 物理療法単独では運動障害の機能回復を期待しな いというのが，リ八関係者の一般的な考え方であ り，常識であるようである。しかし運動療法と物 理療法の役割分担についての以上のようなリ八関 係者の考え方や常識に合理的な根拠があるのだろ うか。

運動障害の機能回復に運動療法が効果的であ り，臨床実績が積み重ねられていることと，物理 療法の有用性の判断とは別個の問題である. 宇宙 空間のような無重力状態では生体組織に骨萎縮や 筋萎縮などの障害が起こることが知られているけ れども5), 無重力に起因する障害の原因的治療は 重力または重力に代わる力学的負荷であり, 遠心 力発生装置や振動装置のような物理療法の機器単 独でも効果が期待できるのである．まず運動療法 ありきで，それ以外のものを補助的治療にしてし まう考え方は見直す必要がある。

\section{運動療法と物理療法の長所と短所}

運動療法の大きな長所は療法士または患者自身 の運動によって, 特別な機器がなくても実施でき ることであろう。しかし運動療法には療法士の技 量や患者の意欲に依存するところが大きいこと や，療法士や患者自身の人的ミスによるリスクと いう弱点がある．可塑性を制御するためには，一 定量の刺激を長期間継続することが必要であるけ れども，同一動作の繰り返し刺激は CPM（持続 的他動運動装置）のような機械のほうが得意であ り，機械であれば安全装置によってリスクを事実 上ゼロに近づけることも不可能ではない.さらに 物理療法は, 患者の意欲が低い時にも機器によっ て実施可能であるから，コンプライアンスを向上 しやすいことも強みである.

以上のような運動療法と物理療法の長短所を考 慮して, 適材適所に構築された理学療法が, これ からの望ましい姿であると考える。 


\section{従来の物理療法はなぜ運動障害の 機能回復に役立たなかったのか}

\section{1. 適切でなかった物理的エネルギー}

従来の物理療法で使用されている物理的エネル ギーの種類や量・時間などは経験的に定められ， 可塑性を制御するためのエネルギーとしては，不 適切であった可能性がある。

われわれは皮膚の抵抗が低く，不快感が少ない 高周波電気パルスを我慢できる限界の強度で健常 者に加え，6週間継続して大腿四頭筋筋力の 約 15\%の増加を得ている6) (図 1)．Bonutti らや Gelinas らは，ターンバックル装具などの静的伸 張力を段階的に加える装具を肘関節拘縮例に使用 して，関節可動域の平均 $30^{\circ}$ 以上の改善をみてい $ろ^{7,8)}$.

以上の結果は，十分な量の物理的エネルギーを 計画的に加えれば運動障害の機能回復が可能なこ とを示すものである.

\section{2. 物理療法は体表面からという固定観念また} は自己規制

成長期の $\mathrm{O}$ 脚を矯正する目的の下肢装具は, 日常生活において継続して装着してくれる症例が ほとんどなく，実際の矯正効果がほとんど見られ ないことは，よく知られていることである。しか し変形矯正のために装具を長期間装着すること自 体が無理かというと，歯科領域では装具による歯 列矯正が普通に行われ，確実な成果を上げている 事実がある．整形外科的装具と歯科の歯列矯正装

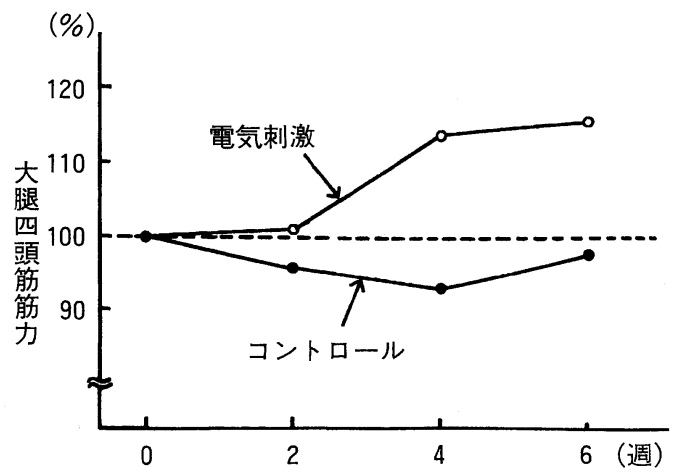

図 1 電気刺激による健常人の筋力強化
具の違いは，皮膚を介するか，歯に直接矯正力を 働かせるかである. 皮膚を介すると不快感を伴 い，裖瘡をつくることもあるが，歯に力をかけて もそのようなことは起こりにくい. 整形外科的に も骨格に金属ピンを打ち込んで，直接矯正力を作 用させれば，苦痛は少なく，臨床的にも矯正効果 をあげることができることは，イリザロフ法など の創外固定法で示されている ${ }^{9)}$ (図 2). 形成外科 では皮膚伸展法といって，皮下にシリコン製バッ グを埋め込んで，時間をかけて水を注入し，皮膚 を内部からの圧力で伸展させて余剰皮膚を作成 し，皮膚欠損部に使用する方法が実用化されてい る ${ }^{10)}$. 以上のように，目的とする生体組織に直接 力学的負荷（メカニカルストレス）を作用させる ことができれば，変形を矯正したり，拘縮を治療 することが比較的容易に行えるのである ${ }^{11}$.

一方，かつては経口投与と皮下や静脈注射の手 段しか持たなかった内科医が，現在では必要な薬 物を必要な時間に必要な部位で作用させるための DDS システム（Drug Delivery System）の応用 である経皮的薬剤吸収の技術を用いているかと思 えば，内科医自身が中心静脈にカテーテルを挿入 して高カロリー輸液を行ったり，抗ガン剤の高濃 度注入を行い, 内視鏡手術まで行っている現状を 見ていると，「物理療法は体表面から」というリ 八関係者の固定観念あるいは自己規制は根本的に 見直す時期にあるのではないだろうか.

\section{3. 物理療法の定義の曖昧性}

理学療法における運動療法と物理療法の境界に

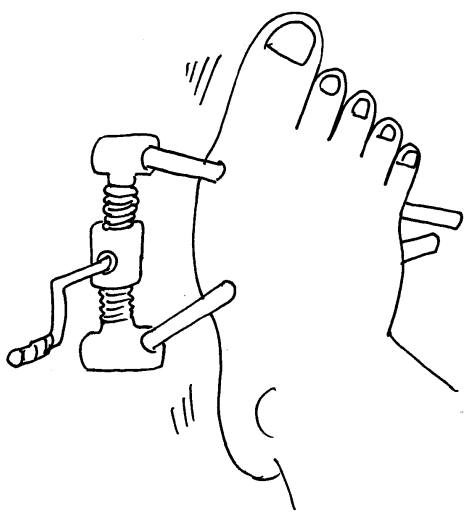

図 2 内反足矯正の創外固定 


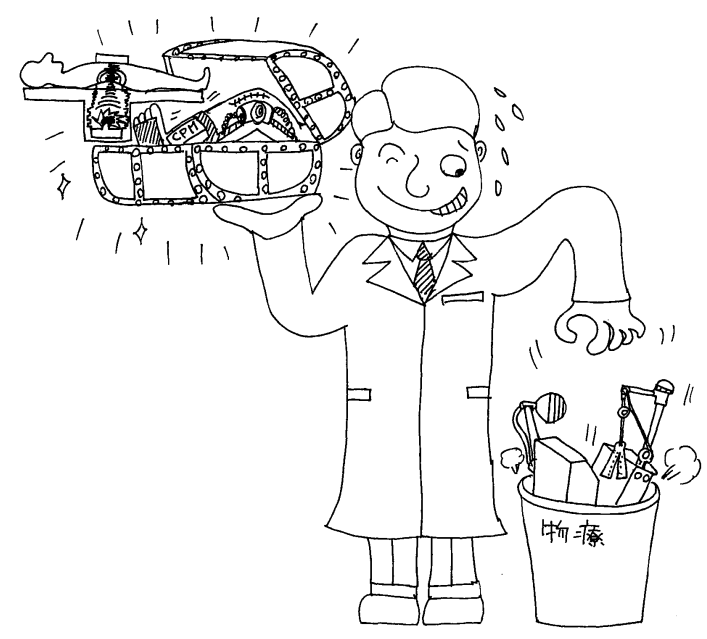

図 3 役に立たないものは物療に

は曖昧なところがある。牽引療法は物理療法とさ れるが，物理的エネルギーそのものである放射線 療法や超音波結石破砕術が物理療法の範疇外に置 かれ，同じように機器を使用する CPM（持続的 他動運動装置）は一般的には運動療法と見なされ ている。素直でない見方かもしれないが, 役に立 つものは運動療法か他の治療法に振り分け, 役に 立たないものだけを物理療法（いわゆる物療）と いうごみ箱に押し込める傾向があったというと言 い過ぎであろうか（図 3).

\section{4. 物理療法は役に立たないという誤解}

リ八関係者の中には, 物理療法は役に立たない ものと考えている方が少なくないようである.し かし上述した電気刺激による筋力増強効果や, 装 具による拘縮の改善，イリザロフ法で明かなよう に, 物理的エネルギーによる運動障害の改善は可 能である。

運動障害以外を対象とする領域でも, 臨床的成 果をあげて使用されている物理療法がある。たと えば新生児黄㾝に対する光線療法は, 現在ではそ の作用機序も解明され, 交換輸血とともに新生児 黄疸の不可欠な治療法となっている ${ }^{12)}$. またイオ ン導入療法とも呼ばれるイオントフォレーシス は, 従来から物理療法に含まれている治療法であ るが，われわれは水道水を用いるイオントフォレ ーシスを多汗症に用い，1日1回，20 分の治療を

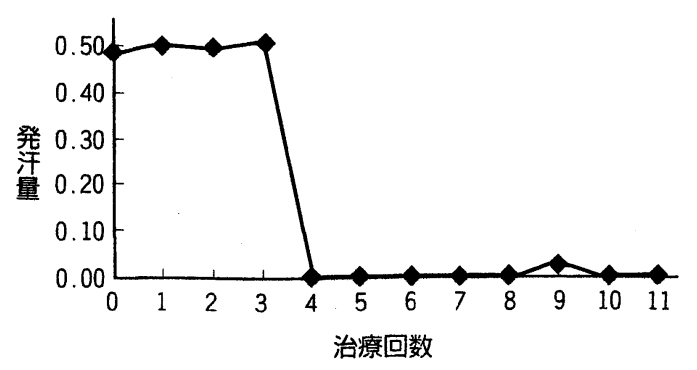

図 4 イオントフォレーシスによる多汗症の治療

数回繰り返すことによって発汗量の著明な減少を 認めている ${ }^{13)}$ (図 4).

一方再生医学では, 培養器内で作成した骨や軟 骨のような支持組織は, 移植しても力学的強度が 獲得できるまでに長時間を要するので, 移植前の 物理的刺激の必要性が強調されてきている ${ }^{14)}$.

いまや物理療法が役に立たないと考えているの は，リ八関係者のみであるかもしれない.しかし 物理療法を役に立たないものにしてしまった原因 は，「物理療法は役に立たない」という誤解から， 基礎研究や技術開発の努力を急ってきたリ八関係 者自身にあるかもしれないのである.

\section{むすび}

物理的エネルギー（物理療法）による運動障害 の機能回復の可能性は十分あるけれども, 臨床的 に広く使用できるようにするためには，基盤的研 究開発（インフラストラクチャー）の整備と推進 が必要である。そのためにはまず，「物理療法は 役に立たない」「物理療法は皮膚の表面から」な どの関係者の固定観念を見直すことから始める必 要があろう。

\section{文献}

1）上田 敏：中枢神経障害における機能回復のメカニズ ム、リハビリテーション基礎医学（上田 敏, 千野直 一, 岩倉博光 編). 医学書院, 東京, 1983 ; pp 148-164

2) 川村次郎：リモデリングーリハビリテーションに扔け る生体組織制御への挑戦一（第 6 回カレントトピック ス\&レクチャー基調講演抄録). リ八専門医ニュース 1994 ; No. 9: 3-6

3）岩谷 力, 佐直信彦, 飛松好子: 運動障害のリハビリ テーション. 南江堂, 東京, 2002

4) Cameron MH (眞野行生, 渡部一郎 監訳) : Phyical Agents in Rehabilitation (EBM 物理療法). 医歯薬出 
版, 東京, 2003

5）志波直人，岩佐聖彦，前田貴司ほか：宇宙空間で有効 な筋力維持装置開発の研究. 第 18 回バイオメカニズ ム・シンポジウム 前刷, 久住高原荘, 2003 ; pp 157164

6）川村次郎：電気刺激による筋力増強. リ八医学 1996 ; 33: $96-97$

7) Bonutti PM, Windau JE, Ables BA, et al : Static progressive stretch to reestablish elbow range of motion. Clin Orthop 1994 ; 303 : 128-134

8) Gelinas JJ, Faber KJ, Patterson SD, et al: The effectiveness of turnbuckle splinting for elbow contractures. J Bone Joint Surg 2000 ; 82-B : 74-78

9）富 雅男: 幼児期発症内反足に対する Illizarov 創外 固定器による変形矯正術. 整形外科 $1998 ; 49$ : 10411048

10）西 正行, 神崎 保: 皮膚伸展法. 医学のあゆみ 1997 ; 181 : 1063-1066

11）赤居正美 : 筋骨格系に対するメカニカルストレスの効 果. 現代医療 $2000 ； 32: 1484-1489$

12) Dobbs RH, Cremer RJ : Phototherapy. Arch Dis Child $1975 ; \mathbf{5 0}: 833-836$

13）川村次郎：TES一治療的電気刺激. 臨床リハ 1998； 7 : 484-489

14）牛田多加志: 物理的刺激による組織再性の促進一軟骨 再生と静水圧一. BME $2002 ； 16(2): 25-32$ 